\title{
Article \\ Characterization of Protocatechuate 4,5-Dioxygenase from Pseudarthrobacter phenanthrenivorans Sphe3 and In Situ Reaction Monitoring in the NMR Tube
}

\author{
Epameinondas Tsagogiannis ${ }^{1}$, Elpiniki Vandera ${ }^{1,+}$, Alexandra Primikyri ${ }^{2,+}{ }^{\circledR}$, Stamatia Asimakoula ${ }^{1}$, \\ Andreas G. Tzakos ${ }^{2} \mathbb{D}$, Ioannis P. Gerothanassis ${ }^{2} \mathbb{D}$ and Anna-Irini Koukkou ${ }^{1, *}$ \\ 1 Laboratory of Biochemistry, Sector of Organic Chemistry and Biochemistry, Department of Chemistry, \\ University of Ioannina, 45110 Ioannina, Greece; e.tsagkogiannis@uoi.gr (E.T.); evandera@uoi.gr (E.V.); \\ s.asimakoula@uoi.gr (S.A.) \\ 2 Laboratory of Organic Chemistry, Sector of Organic Chemistry and Biochemistry, Department of Chemistry, \\ University of Ioannina, 45110 Ioannina, Greece; a.primikyri@uoi.gr (A.P.); atzakos@uoi.gr (A.G.T.); \\ igeroth@uoi.gr (I.P.G.) \\ * Correspondence: akukku@uoi.gr; Tel.: +30-265-100-8371 \\ + Equal contribution.
}

Citation: Tsagogiannis, E.; Vandera, E.; Primikyri, A.; Asimakoula, S.; Tzakos, A.G.; Gerothanassis, I.P.; Koukkou, A.-I. Characterization of Protocatechuate 4,5-Dioxygenase from Pseudarthrobacter phenanthrenivorans Sphe3 and In Situ Reaction Monitoring in the NMR Tube. Int. J. Mol. Sci. 2021, 22, 9647. https://doi.org/10.3390/ijms 22179647

Academic Editor: Jorge H. Leitão

Received: 9 July 2021

Accepted: 2 September 2021

Published: 6 September 202

Publisher's Note: MDPI stays neutral with regard to jurisdictional claims in published maps and institutional affiliations.

Copyright: (c) 2021 by the authors. Licensee MDPI, Basel, Switzerland. This article is an open access article distributed under the terms and conditions of the Creative Commons Attribution (CC BY) license (https:// creativecommons.org/licenses/by/ $4.0 /)$
Abstract: The current study aims at the functional and kinetic characterization of protocatechuate (PCA) 4,5-dioxygenase (PcaA) from Pseudarthrobacter phenanthrenivorans Sphe3. This is the first single subunit Type II dioxygenase characterized in Actinobacteria. RT-PCR analysis demonstrated that $p c a \mathrm{~A}$ and the adjacent putative genes implicated in the PCA meta-cleavage pathway comprise a single transcriptional unit. The recombinant PcaA is highly specific for PCA and exhibits MichaelisMenten kinetics with $\mathrm{K}_{\mathrm{m}}$ and $\mathrm{V}_{\max }$ values of $21 \pm 1.6 \mu \mathrm{M}$ and $44.8 \pm 4.0 \mathrm{U} \times \mathrm{mg}^{-1}$, respectively, in $\mathrm{pH} 9.5$ and at $20^{\circ} \mathrm{C}$. PcaA also converted gallate from a broad range of substrates tested. The enzymatic reaction products were identified and characterized, for the first time, through in situ biotransformation monitoring inside an NMR tube. The PCA reaction product demonstrated a keto-enol tautomerization, whereas the gallate reaction product was present only in the keto form. Moreover, the transcriptional levels of $p c a \mathrm{~A}$ and $p c a \mathrm{R}$ (gene encoding a LysR-type regulator of the pathway) were also determined, showing an induction when cells were grown on PCA and phenanthrene. Studying key enzymes in biodegradation pathways is significant for bioremediation and for efficient biocatalysts development.

Keywords: Pseudarthrobacter phenanthrenivorans Sphe3; protocatechuate (PCA) 4,5-dioxygenase; in situ biotransformation monitoring; NMR bioreactor; extradiol dioxygenases; Actinobacteria

\section{Introduction}

Protocatechuic acid (PCA) is an important ring-cleavage common intermediate formed from the catabolism of low molecular weight polycyclic aromatic hydrocarbons, namely ferulic, vanillic, and $p$-coumaric acid. These compounds are derived from the apopolymerization of lignin, phthalic acid isomers, chlorobenzoic acids, and methylated aromatic hydrocarbons such as toluene and xylene [1].

PCA is further metabolized and funneled to the TCA cycle under aerobic conditions by the action of intradiol or extradiol dioxygenases via three distinct catabolic pathways, differing in the location of the initial ring opening oxidation: 2,3-dioxygenation (para-cleavage pathway) [2,3], 3,4-dioxygenation (ortho-cleavage, known as the $\beta$-ketoadipate pathway) [4], and 4,5-dioxygenation of PCA (meta-cleavage pathway) [5]. Generally, the ortho-cleavage pathway of PCA is widely distributed amongst Actinobacteria and Proteobacteria [6] and PCA 3,4-dioxygenase is the most commonly characterized enzyme [7].

In contrast, homologues of PCA 4,5-dioxygenases (meta-cleavage pathway) were found almost exclusively in Proteobacteria [8,9], whereas Actinobacteria degrade PCA pre- 
dominantly via the ortho-cleavage pathway [9]. Perez-Pantoja and co-workers [10] reported that only the genome of Arthrobacter sp. FB24 among the 53 actinobacterial genomes, analyzed in a phylogenetic study, possesses a PCA 4,5-dioxygenase gene. The meta-cleavage enzymes have been studied less relative to the respective ortho-cleavage enzymes, probably due to their sparser distribution among bacteria and/or their relative instability [11].

The hetero-multimeric PCA 4,5-dioxygenases, composed of two subunits with the encoding genes adjacently located, belong to the PCA dioxygenase (PCAD) of the phosphorylase/peptidyl hydrolase fold (Type II) of extradiol-bond cleaving dioxygenases [12-14]. PCAD superfamily domains exhibit structural and sequence similarities with the Memoprotein superfamily that led Burroughs et al. [14] to their classification as the novel PCADMemo superfamily.

Although numerous biochemical characterizations of the PCA 4,5-dioxygenases have been established in several bacterial groups such as Comamonas species $[5,8,15,16]$, Pseudomonas species [17], Sphingomonas species [12,18-20], Delftia sp. strain TBKNP-05 [21], and Rhizobium leguminosarum [11], until now, the PCA 4,5-dioxygenase (LigAB) from Sphingomonas paucimobilis SYK-6 is the only structurally and fully kinetically characterized enzyme [12].

Pseudarthrobacter phenanthrenivorans Sphe3 (formerly Arthrobacter phenanthrenivorans Sphe3) [22] catabolizes phenanthrene at concentrations up to $400 \mathrm{mg} /$ Las a sole source of carbon and energy at higher rates than those reported for any other member of the genus $[23,24]$. In silico analysis of the Sphe3 genome [25] revealed putative gene clusters on PASPHE302 plasmid and the chromosome, implicated in the meta- and ortho-cleavage of PCA, respectively, in contrast to other members of the genus Arthrobacter that catabolize PCA only via the ortho-cleavage pathway [26-28]. The presence of both ortho- and metacleavage pathways in Sphe3 was also validated through proteomic analysis [29]. Although the occurrence of meta-cleavage of PCA has also been demonstrated in Arthrobacter keyseri 12B [30] as well as in other Actinobacteria [31], there is no study on the kinetic characterization of PCA 4,5- dioxygenase in this phylum. The functional and/or kinetic studies of enzymes belonging to the largely uncharacterized Type II extradiol dioxygenase clade of the PCAD-Memo superfamily will allow comparisons among these enzymes, thus shedding more light on this Type in the dioxygenase superfamily.

In the present study, we report the heterologous expression in E. coli and biochemical characterization of the recombinant PCA 4,5-dioxygenase (PcaA). Substrate specificity of the enzyme was also assessed and NMR spectroscopy was employed for the in situ monitoring of PCA biotransformation by PcaA and the identification of its products. To our knowledge, this is the first report on the biochemical characterization of the PCA 4,5-dioxygenase from the genus Arthrobacter and recording in real-time the formation of biotransformation products using a $5 \mathrm{~mm}$ NMR tube bioreactor.

Furthermore, the co-transcription of the genes involved in the PCA 4,5-cleavage pathway was demonstrated using RT-PCR, and the transcriptional levels of the genes encoding the PCA 4,5-dioxygenase and a LysR-type regulator of the 4,5-cleavage pathway were analyzed by quantitative real-time PCR (RT-qPCR) in cells grown in the presence of phenanthrene and protocatechuic acid.

\section{Results}

\subsection{PCA 4,5-Dioxygenase Activity and Transcriptional Analysis with RT-PCR and RT-qPCR}

The activity of PcaA was measured in a crude extract of mid logarithmic phase Sphe3 cells grown on phenanthrene, PCA, or glucose. Higher activity was recorded in cells grown on PCA $\left(0.025 \mathrm{U} \times \mathrm{mg}^{-1}\right)$ than on phenanthrene $\left(0.012 \mathrm{U} \times \mathrm{mg}^{-1}\right)$ whereas no activity was detected in cells grown on glucose. To confirm the transcriptional induction of the PcaA, its expression was monitored by RT-qPCR in cultures of Sphe3 on M9 with glucose, phenanthrene, or PCA as the sole carbon source. The expression of pcaA gene was induced in cells grown on phenanthrene or PCA showing up to 139- and 304-fold change increase 
in mRNA expression levels in the presence of phenanthrene and PCA, respectively, when compared to glucose (Figure 1).

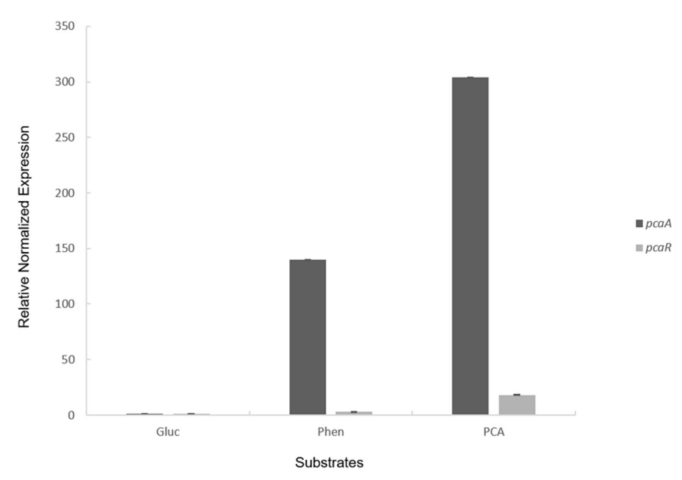

Figure 1. $p c a \mathrm{~A}$ and $p c a \mathrm{R}$ gene expression quantification monitored by RT-qPCR in P. phenanthrenivorans Sphe3 grown on glucose, phenanthrene, and PCA as the sole carbon and energy source. Values represent the mean relative $p c a \mathrm{~A}$ and $p c a \mathrm{R}$ expression normalized to the housekeeping gene $g y r \beta \pm$ standard deviations of three individual replicates. Gene expression levels in glucose were used as calibrator.

In strain Sphe3, a pcaR gene encoding a LysR-type transcriptional regulatory protein was identified upstream of the respective operon and inversely oriented to the rest of the genes (Figure 2a). The expression of $p c a \mathrm{R}$ was induced during growth on phenanthrene or PCA. However, higher expression of pcaR on PCA (18-fold) than on phenanthrene (3-fold) was observed, whereas a minimal transcription of $p c a \mathrm{R}$ was detected in cultures grown in the presence of glucose. These results indicate a regulation but with a basal constitutive expression of $p c a$ R gene (Figure 1). Transcriptional analysis with RT-PCR resulted in amplification products of the predicted sizes in all cases (Figure 2b), suggesting that PCA 4,5-pathway genes are transcribed as a single transcriptional unit.

$\mathbf{a}$

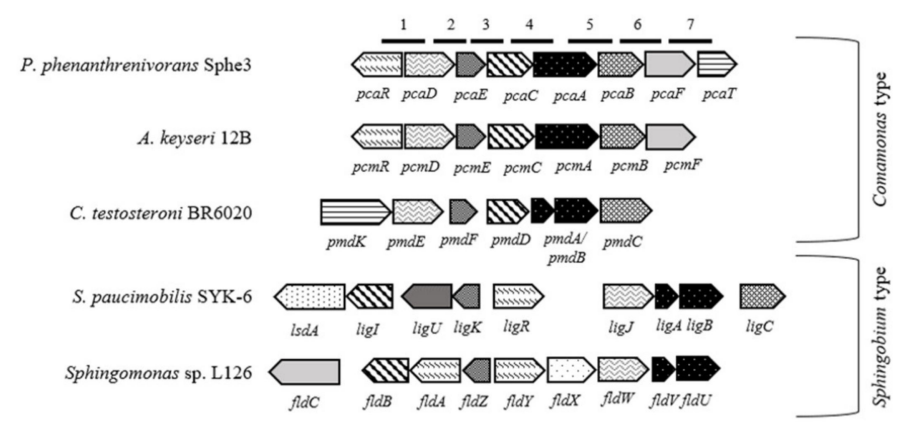

b

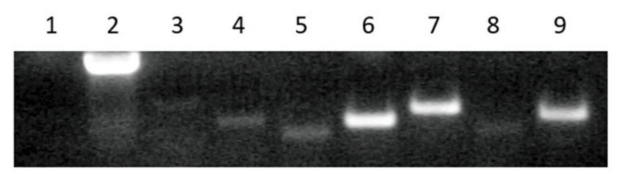

Figure 2. (a) Sphingobium and Comamonas types of genetic organization of gene clusters from the PCA 4,5-dioxygenation pathway in various microorganisms [16,19,20,30]. Genes: pcaR (Asphe3_42340), $p c m \mathrm{R}, f l d \mathrm{Y}$, putative transcriptional regulatory gene; ligR, transcriptional regulatory gene; $p c a \mathrm{D}$ (Asphe3_42350), pcm D, pmdE, ligJ, fldW, OMA hydratase; $p c a \mathrm{E}$ (Asphe3_42360), pcmE, pmdE, ligK, fldZ, CHA aldolase; $p c a \mathrm{C}$ (Asphe3_42370), $p c m \mathrm{C}$, pmdD, ligI, fldB, PDC hydrolase; $p c a \mathrm{~A}$ (Asphe3_42380), $p c m \mathrm{~A}, \mathrm{PCA} 4,5$-dioxygenase; $p m d \mathrm{~A}$, ligA, fld $\mathrm{V}, \alpha$-subunit of PCA 4,5-dioxygenase; $p m d \mathrm{~B}$, lig $\mathrm{B}, f l d \mathrm{U}$, $\beta$-subunit of PCA 4,5-dioxygenase; $p c a \mathrm{~B}$ (Asphe_42390), pcm B, pmdC, ligC, CHMS dehydrogenase; $p c m \mathrm{~F}$, fld C, putative alcohol dehydrogenase; $p c a \mathrm{G}$ (Asphe_42400), putative oxidoreductase, arylalcohol dehydrogenase like protein; pcaT (Asphe3_42410), ABC-type molybdate transport system; 
lsdA, putative lignostilbene $\alpha, \beta$-dioxygenase; lig $\mathrm{U}$, fldA, 4-oxalomesaconate tautomerase. Numbered lines on the top part of the image indicate the regions according to which primers were designed in order study whether the genes of PCA 4,5-dioxygenation pathway are part of the same transcription unit, with reverse transcription-PCR, as follows: 1. pcaRT1, 2. pcaRT2, 3. pcaRT3, 4. pcaRT4, 5. pcaRT5, 6. pcaRT6, pcaRT7 (also see Table S1). (b) Agarose gel electrophoresis of co-transcription products of RT-PCR. Lane 1. no DNA control, 2. positive DNA control, 3. pcaRT1 product, 4. pcaRT2 product, 5. pcaRT3 product, 6. pcaRT4 product, 7. pcaRT5 product, 8. pcaRT6 product, 9. pcaRT7 product.

In strain Sphe3, a single subunit which contains the regions corresponding to the $\alpha$ and $\beta$ subunit of PCA 4,5-dioxygenases at the $\mathrm{N}$ - and C-terminals, respectively, was identified by in silico analysis of the genome, something that was also previously reported for strain A. keyseri 12B [30].

The predicted protein product of the PCA 4,5-dioxygenase gene shared $99 \%$ sequence identity with the PCA 4,5-dioxygenase from A. keyseri 12B [30] at the amino acid level. The catalytic $\beta$ subunit of the enzyme also shares $67 \%$ and $66 \%$ amino acid sequence identity with the $\beta$ subunits of PCA 4,5-dioxygenases from C. testosteroni [15] and P. straminea [17], respectively. Multiple sequence alignment of PcaA with other extradiol dioxygenases using CLUSTALW algorithm revealed key conserved features of the enzyme (Figure S1). Phylogenetic and molecular evolutionary analysis of PcaA using amino acid sequences with MEGA algorithm, showed that P. phenanthrenivorans is in the same sister taxon of Arthrobacter sp. FB24, Arthrobacter sp. J3.49, and A. keyseri 12B (Figure 3).

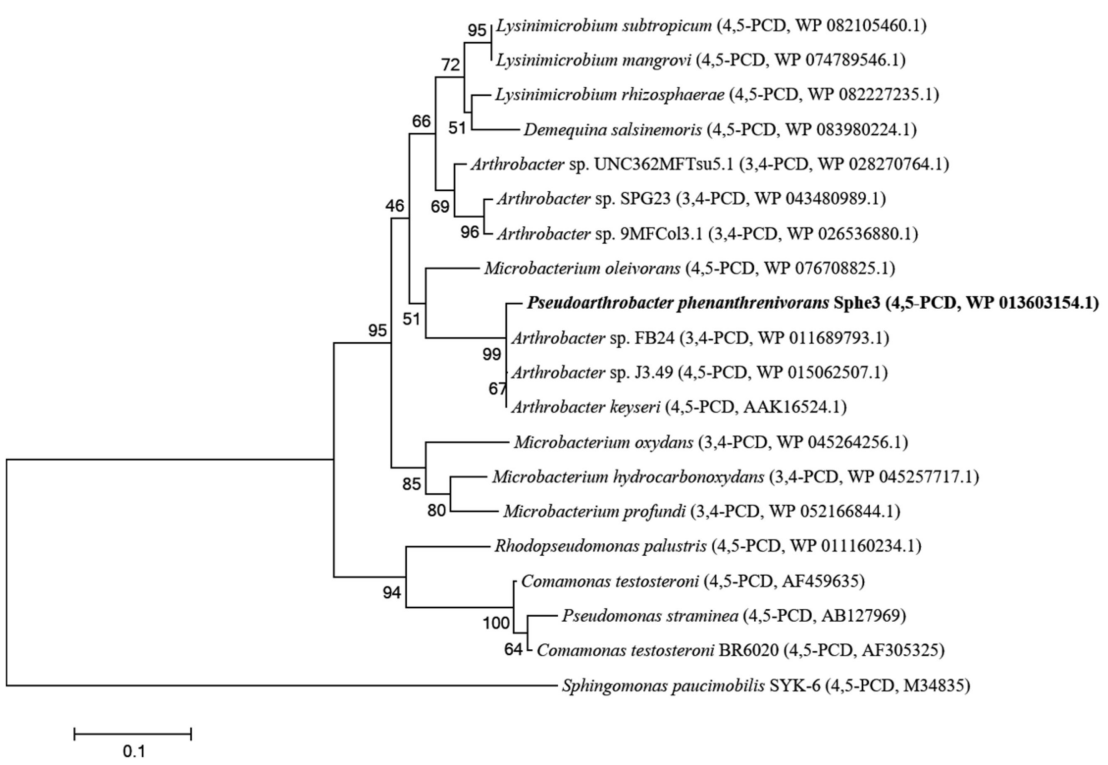

Figure 3. Phylogenetic tree of PcaA and other PCA dioxygenases. The dioxygenases used for the construction of the phylogenetic tree presented $>66 \%$ identity with PcaA. The tree was constructed with the neighbor joining algorithm. The percentage of replicate trees in which the associated dioxygenases clustered together in the bootstrap test (500 replicates) is shown next to the branches. The scale bar indicates the number of substitutions per nucleotide position. Accession numbers are in parentheses. 3,4-PCD: PCA 3,4-dioxygenase; 4,5-PCD: PCA 4,5-dioxygenase.

\subsection{Heterologous Expression and Catalytic Properties of the Recombinant PcaA}

The recombinant PcaA resulted in a protein band of $\sim 45 \mathrm{kDa}$, as determined by SDS-PAGE analysis (Figure S2), corresponding well to the in silico predicted MW of $48 \mathrm{kDa}$. The recombinant enzyme was active within $\mathrm{pH} 5.5$ and 10.5, with an optimum at $\mathrm{pH}$ 9.5, when spectrophotometrically determined, while at $\mathrm{pH} 5.0$ and $\mathrm{pH} 11.0$, the enzyme completely lost its activity. The enzymatic reaction product, 4-carboxy-2-hydroxymuconate6-semialdehyde (CHMS), exhibits a yellow color with an absorption maximum in alkaline 
solution ( $\mathrm{pH}$ 9.0) [32]. In order to examine if the higher activity is due to the higher absorbance in $\mathrm{pH}$ 9.5, PcaA activity was recorded in the same $\mathrm{pH}$ range by $\mathrm{O}_{2}$ consumption rate. These measurements were also consistent with the spectrophotometric determination further verifying that the optimum $\mathrm{pH}$ for $\mathrm{PcaA}$ is 9.5. The effect of temperature on PcaA activity was evaluated in $100 \mathrm{mM}$ Glycine- $\mathrm{NaOH}$ buffer $(\mathrm{pH}$ 9.5) at temperatures ranging between $5{ }^{\circ} \mathrm{C}$ and $50{ }^{\circ} \mathrm{C}$. The enzyme was found to be active between $10^{\circ} \mathrm{C}$ and $45^{\circ} \mathrm{C}$ with an optimum activity at $20^{\circ} \mathrm{C}$. Its activity was remarkably reduced to $20 \%$ relative activity at $10^{\circ} \mathrm{C}$ and $45^{\circ} \mathrm{C}$.

The recombinant PcaA exhibited PCA 4,5-dioxygenase activity estimated at $6.18 \mathrm{U}$ $\times \mathrm{mg}^{-1}$, at the optima pH 9.5 and $20^{\circ} \mathrm{C}$. After incubation of the enzyme with $0.2 \mathrm{mM} \mathrm{Fe}$ (II) and L-ascorbic acid, a significant increase, more than a 6-fold, in specific activity was observed $\left(39.65 \mathrm{U} \times \mathrm{mg}^{-1}\right)$. The apparent $K_{m}$ value of PcaA for PCA as estimated at $20{ }^{\circ} \mathrm{C}$ was $21 \pm 1.6 \mu \mathrm{M}$ and the $\mathrm{V}_{\max }$ was found $44.8 \pm 4.0 \mathrm{U} \times \mathrm{mg}^{-1}$.

Incubation of PcaA with metal-chelating agents such as bipy, EDTA or o-phenanthroline, was insufficient to significantly decrease the PcaA activity (data not shown). On the other hand, incubation with various concentrations of $\mathrm{Cu}(\mathrm{II})$ and $\mathrm{Mn}$ (II) exhibited strong inhibitory effects (the enzyme lost $87 \%$ and $57 \%$ of its relative activity, respectively), unlike $\mathrm{Mg}(\mathrm{II})$ and $\mathrm{Ni}(\mathrm{II})$, which caused no significant inhibition (less than $10 \%$ inhibition in both cases).

The purified enzyme maintained $93 \%$ of its activity for up to at least 4 months upon storage at $-80{ }^{\circ} \mathrm{C}$ in the presence of $10 \%(v / v)$ glycerol. High levels of activity maintenance were recorded in the presence of $1 \%(v / v)$ DMSO, while ethanol $(10 \%(v / v))$ or higher DMSO concentrations $(10 \%(v / v))$ failed to maintain high levels of activity.

\subsection{Substrate Specificity}

Of the potential substrates that were evaluated, only gallate (5-hydroxyprotocatechuate) exhibited oxygen consumption activity, corresponding to $44 \%$ of the enzyme's activity. No activity was recorded with homoprotocatechuate (3,4-dihydroxyphenylacetate) or any of the other substrates tested that contain the catechol scaffold.

\subsection{In Situ Monitoring of the PcaA Enzymatic Reaction Using PCA or Gallate as Substrates in the NMR Tube Bioreactor}

The in situ monitoring of the enzymatic reaction of the PCA or gallate biotransformation products was performed, for the first time, using a $5 \mathrm{~mm}$ NMR tube bioreactor $[33,34]$. For this, $1 \mathrm{mM}$ of the substrate was added to $8 \mu \mathrm{M}$ of PcaA in a $5 \mathrm{~mm}$ NMR tube and 1D and 2D NMR data were recorded. Figure 4a illustrates the progress of the enzymatic reaction 2 and $24 \mathrm{~h}$ after the addition of the PCA in the NMR tube. After $2 \mathrm{~h}$, approximately $8 \%$ of PCA was converted to the 4-carboxy-2-hydroxymuconate-6-semialdehyde (CHMS) product (Figure $4 \mathrm{ai}$ ), while $24 \mathrm{~h}$ later, the PCA was totally consumed by 4,5-dioxygenase (Figure 4aii). The $1 \mathrm{D}^{1} \mathrm{H}$ NMR spectrum of CHMS exhibited a characteristic deshielded doublet resonance at $9.17 \mathrm{ppm}$ (Figure $4 \mathrm{~b}$ ) which was attributed to the aldehyde proton H6e. Further, a doublet at $8.45 \mathrm{ppm}$ was assigned to H5e and a singlet resonance at $8.84 \mathrm{ppm}$ was attributed to H3e. It should be emphasized that the ${ }^{1} \mathrm{H}$ NMR resonances of $\mathrm{PcaA}$ are invisible due to extensive line broadening and the very low concentration $(8 \mu \mathrm{M})$ relative to that of PCA $(1 \mathrm{mM})$. The control assay is the ${ }^{1} \mathrm{H}$ NMR spectrum of the biotransformation of PCA by PcaA inside the NMR tube at $0 \mathrm{~h}$ (no observable signals of the biotransformation product, Figure S3), followed by the ${ }^{1} \mathrm{H}$ NMR spectrum after $2 \mathrm{~h}$ of reaction (very weak signals of the reaction product, Figure $4 \mathrm{a}$ ) and $24 \mathrm{~h}$ (Figure $4 \mathrm{~b}$ )

Following the enzymatic reaction in the NMR tube also allowed to record, as is illustrated in Figure $4 \mathrm{~b}$, the keto-enol tautomerization, since two reaction products were unveiled. The keto form, which is the minor CHMS product, demonstrated a less deshielded resonance at $8.81 \mathrm{ppm}$ due to H6k proton. Proton H5k showed a doublet at $7.98 \mathrm{ppm}$ and the two $\mathrm{H} 3 \mathrm{k}$ protons resonances appeared at 7.91 and $8.01 \mathrm{ppm}$. The excellent resolution and signal to noise ratio of the recorded $1 \mathrm{D}^{1} \mathrm{H}$ spectra allowed the application of various $2 \mathrm{D}$ NMR experiments. The ${ }^{1} \mathrm{H}-{ }^{-1} \mathrm{H}$ COSY NMR spectrum demonstrated a characteristic cross-peak 
between $\mathrm{H} 5$ and $\mathrm{H} 6$ protons for both the keto and enol forms. In the ${ }^{1} \mathrm{H}-{ }^{1} \mathrm{H}$ TOCSY NMR spectrum an intense cross-peak between $\mathrm{H} 5$ and $\mathrm{H} 6$ protons appeared for both the keto and enol form and two less intense cross-peaks between $\mathrm{H} 3$ and $\mathrm{H} 5$ protons and $\mathrm{H} 3$ and $\mathrm{H} 6$ protons for both tautomeric forms (Figure S4).

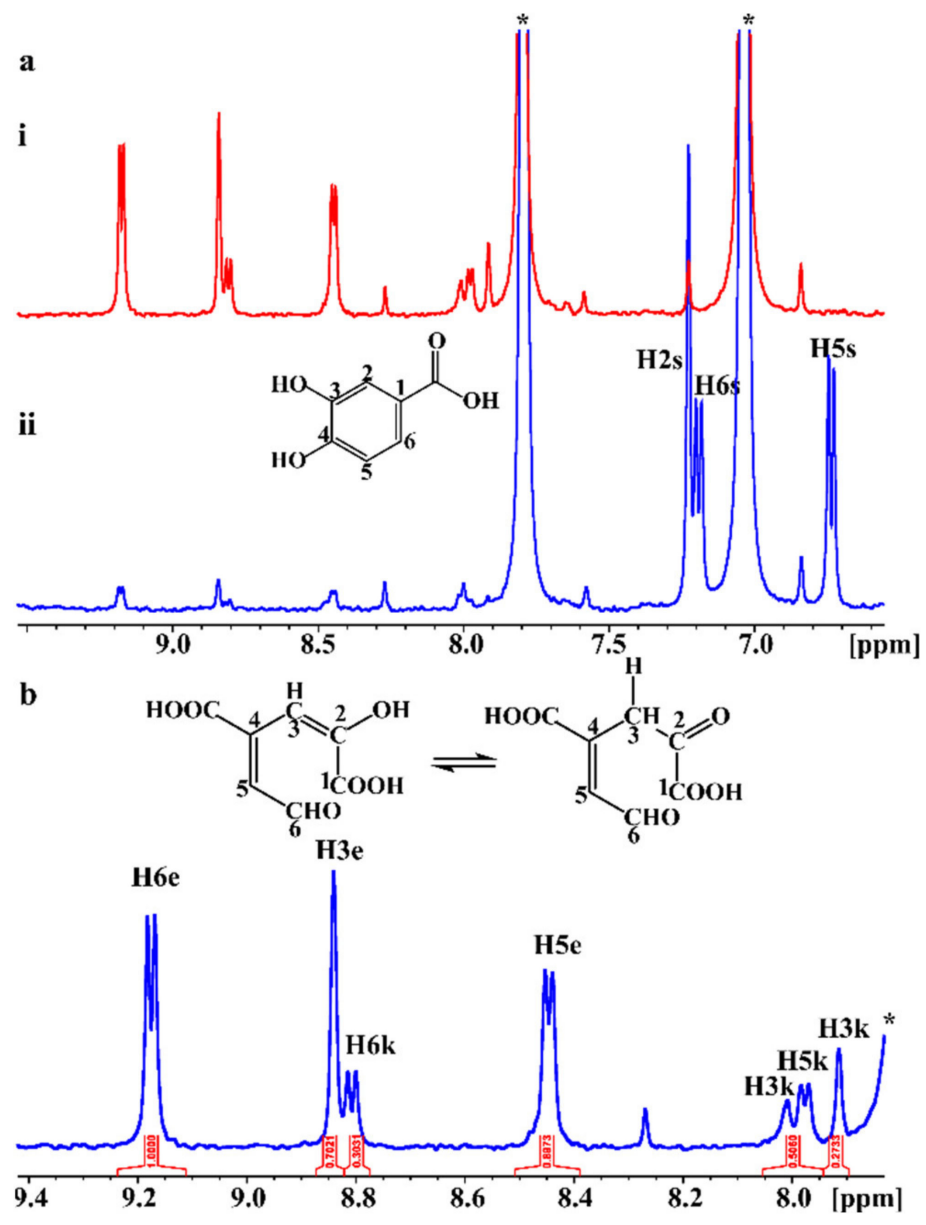

Figure 4. In situ monitoring of the biotransformation of PCA by PcaA, inside the NMR tube. (a) ${ }^{1} \mathrm{H}$ NMR spectra $2 \mathrm{~h}$ (blue spectrum, (i)) and $24 \mathrm{~h}$ (red spectrum, (ii)) after the addition of PCA to PCA 4,5 dioxygenase. ${ }^{1} \mathrm{H}$ NMR resonances of the substrate are shown in the blue spectrum. The asterisk ${ }^{*}$ ) denotes protons of imidazole present in the buffer. (b) Expanded region (7.8-9.4 ppm) of the ${ }^{1} \mathrm{H} \mathrm{NMR}$ spectrum of Figure 4aii and the chemical structures of the enol (left) and keto (right) forms (number of scans $=64$, acquisition time $=4 \mathrm{~s}$, relaxation delay $=1.5 \mathrm{~s}$, total experimental time $=6 \min 22 \mathrm{~s}$ ).

The $2 \mathrm{D}^{1} \mathrm{H}_{-}{ }^{13} \mathrm{C}$ HSQC and HMBC NMR spectra allowed the complete assignment of the carbon chemical shifts for both the keto and enol forms. ${ }^{13} \mathrm{C}$ chemical shifts at 144.55 , 130.05 , and 129.39 were attributed to C6, C5, and C 3 of the enol form, respectively. The $\mathrm{C} 6$, C5, and C3 carbons of the keto form were assigned at 145.29, 124.37, and $126.23 \mathrm{ppm}$, respectively. Informative ${ }^{1} \mathrm{H}_{-}{ }^{13} \mathrm{C}$ HMBC NMR cross-peaks were observed between H6e and $\mathrm{C} 5$ and $\mathrm{C} 3, \mathrm{H} 3 \mathrm{e}$ and $\mathrm{C} 5$, and between $\mathrm{H} 5 \mathrm{e}$ and $\mathrm{C} 3$ and $\mathrm{C} 6$ of the enol form. No cross-peaks were recorded in the ${ }^{1} \mathrm{H}_{-}{ }^{13} \mathrm{C}$ HMBC spectrum for the keto form due to its low abundance in the enzymatic reaction.

STD NMR methodology has previously been applied to simultaneously screen for interactions of the biotransformation products with protein targets in the NMR tube [33,34]. This NMR technique is based on the intermolecular transfer of magnetization from the irradiated protein receptor to the ligand resulting in the determination of interacting protons that are in proximity to the protein $(\leq 5 \AA)$ [35]. Herein, we applied the reverse effect and successfully irradiated the H6e proton of the enol form. Interestingly, magnetization 
was transferred not only to H5e proton of the same molecule via spin diffusion, through the nuclear Overhauser effect, which resulted in a negative peak, but also to the H6k proton of the keto tautomer which appeared as a positive peak, possibly due to the rapid interexchange of the enol-keto forms on the tautomerism (Figure 5). To the best of our knowledge, this is the first demonstration of such an effect with STD NMR methodology.

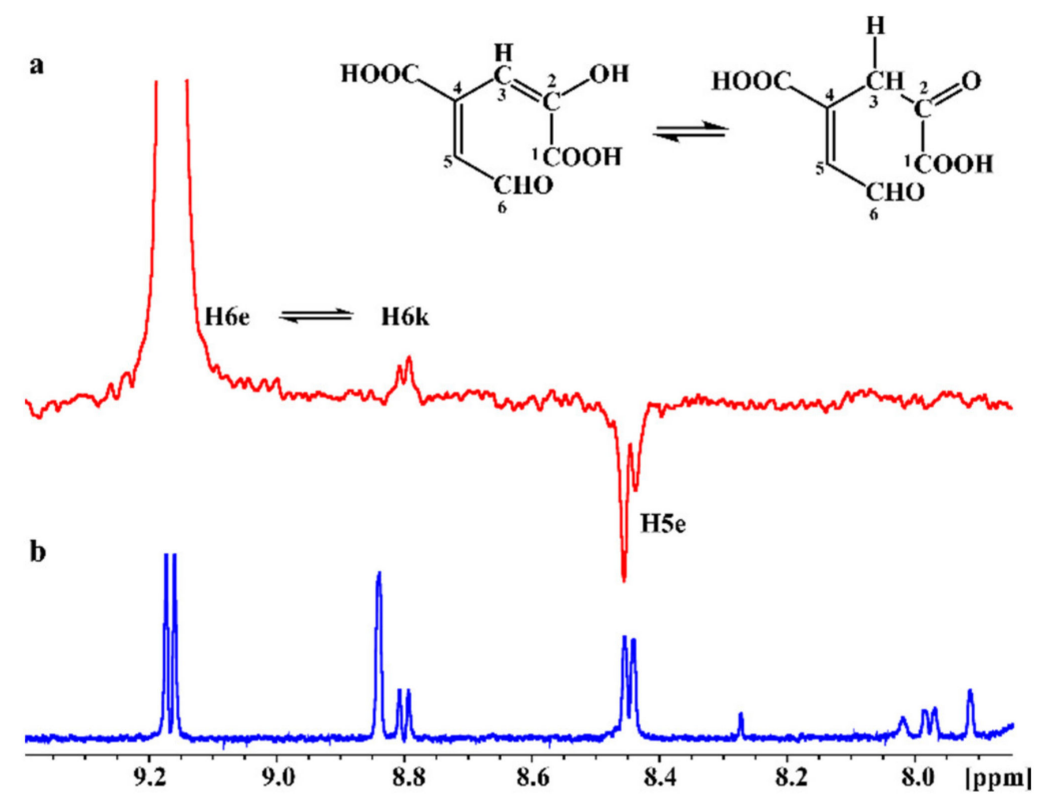

Figure 5. (a) STD NMR spectrum of the enzymatic biotransformation of PCA by 4,5-dioxygenase to the reaction product, CHMS, inside the NMR tube. Irradiation was applied selectively on the H6e proton resonance of the enol form. (b) ${ }^{1} \mathrm{H}$ NMR spectrum of the same sample.

Finally, the equilibrium of the two tautomers was investigated by the use of variable temperature gradient ${ }^{1} \mathrm{H}$ NMR spectroscopy in the buffer solution at $\mathrm{pH} 8$. It should be noted that at the $\mathrm{pH}$ value used, the carboxylic groups are deprotonated. The keto/enol equilibrium of the product was described by the equilibrium constant $\mathrm{K}_{\mathrm{eq}}$ as described in the Supplemental Material [36,37]. The two well-resolved resonances of H3e and H3k were recorded as the enol and keto equilibrium markers, respectively, over a sufficient range of temperatures (290-315 K), which allowed the accurate determination of $\ln K_{\mathrm{eq}}$ (Figure S5) and, therefore, of $\Delta \mathrm{H}^{\circ}$ and $\Delta \mathrm{S}^{\circ}$. The thermodynamic parameters were calculated $\Delta \mathrm{H}^{\circ}=25.58 \mathrm{~kJ} / \mathrm{mol}$ and $\Delta \mathrm{S}^{\circ}=0.10 \mathrm{~kJ} / \mathrm{mol} \mathrm{K}$. At $298 \mathrm{~K},-\mathrm{T} \Delta \mathrm{S}^{\circ}=-28.69 \mathrm{~kJ} / \mathrm{mol}$ and the free energy difference $\Delta \mathrm{G}^{\circ}$ at $298 \mathrm{~K}$ was found to be $-3.11 \mathrm{~kJ} / \mathrm{mol}$.

The progress of the biotransformation of gallate as the substrate after 24 and $48 \mathrm{~h}$ within the NMR tube is illustrated in Figure 6a. After $24 \mathrm{~h}$, approximately, 59\% of gallate was biotransformed, through ring-cleavage reaction to the 4-oxalomesaconic acid product, while $48 \mathrm{~h}$ later, all the substrate was consumed. Application of 1D (Figure 6b) and 2D NMR spectroscopy allowed the characterization of the keto form of the product in the NMR reaction tube. The peak at $6.54 \mathrm{ppm}$ can be assigned to the olefinic H6k proton and the deshielded resonance at $3.89 \mathrm{ppm}$ to the two H3k protons. Similarly, $2 \mathrm{D}{ }^{1} \mathrm{H}-{ }^{13} \mathrm{C}$ HSQC and HMBC NMR spectra allowed the complete assignment of the chemical shifts of the carbons of the product. The resonances at 39.73, 132.7, 137.2, 174.7, and 201.9 ppm can be assigned to carbons $\mathrm{C} 3, \mathrm{C} 6, \mathrm{C} 4, \mathrm{C} 5$, and C2, respectively. Informative ${ }^{1} \mathrm{H}_{-}{ }^{13} \mathrm{C}$ HMBC NMR cross-peaks were observed among $\mathrm{H} 3 \mathrm{k}$ protons and $\mathrm{C} 6, \mathrm{C} 4, \mathrm{C} 5$, and $\mathrm{C} 2$ in the spectrum. For $\mathrm{H} 6$ proton, only cross-peaks with $\mathrm{C} 3$ and $\mathrm{C} 5$ were observed in the ${ }^{1} \mathrm{H}_{-}{ }^{13} \mathrm{C} \mathrm{HMBC}$ spectrum due to the low concentration of the product. 


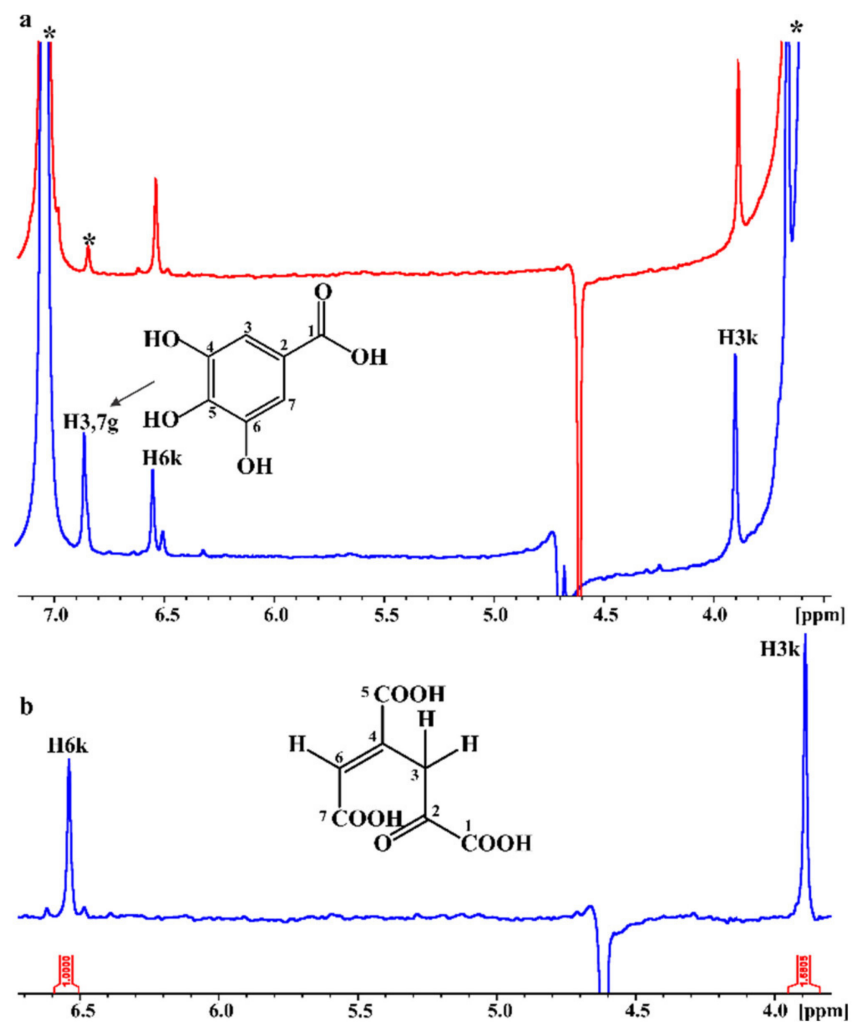

Figure 6. In situ monitoring of the biotransformation of gallate by PcaA, inside the NMR tube. (a) ${ }^{1} \mathrm{H}$ NMR spectra $24 \mathrm{~h}$ (blue spectrum) and $48 \mathrm{~h}$ (red spectrum) after the addition of the substrate to PCA 4,5-dioxygenase. Proton NMR resonances of the substrate are shown in the blue spectrum. The asterisks $\left({ }^{*}\right)$ denote peaks of the Tris-buffer $(3.5 \mathrm{ppm})$, the imidazole $(7 \mathrm{ppm})$, and the carbon satellite of imidazole (6.8 ppm). (b) Expanded region of the ${ }^{1} \mathrm{H}$ NMR spectrum of the OMA keto form enzymatic reaction products (the integrals of the three protons are presented) (number of scans $=64$, acquisition time $=4 \mathrm{~s}$, relaxation delay $=1.5 \mathrm{~s}$, total experimental time $=6 \min 22 \mathrm{~s}$ ).

\section{Discussion}

We have formerly demonstrated that $P$. phenanthrenivorans Sphe3, isolated from a creosote-oil contaminated soil [24], degrades phenanthrene via o-phthalate, leading to the formation of PCA, which in turn could be metabolized via both 3,4- and 4,5-ring cleavage pathways [29]. In silico analysis of the Sphe3 genome has led to the annotation of all the putative genes involved in the 4,5-cleavage pathway and RT-PCR analysis has revealed that the genes constitute a single transcriptional unit; results that are consistent with those reported for C. testosteroni [15], P. straminea [17], and A. keyseri [30]. The gene organization of the PCA 4,5-cleavage pathway in Sphe3, as results from the comparison with other 4,5-gene clusters (Figure 2a), has been characterized as Comamonas type-consisting of a single transcriptional unit-in contrast to the Sphingobium type of organization, which appears to consist of several transcriptional units [38].

To date, the majority of the studied PCA 4,5-dioxygenases consist of a small $\alpha$ and a large $\beta$ subunit in a heterotetrameric structure $\alpha_{2} \beta_{2}$ as exemplified by LigAB of C. testosteroni enzyme crystal structure [39]; however, PmdAB from C. testosteroni T-2 has been reported to be a heteromultimer $(\alpha \beta)_{4}$ [15], whereas a homodimer enzyme consisting of a single subunit has been reported for Rhizobium leguminosarum biovar viceae USDA 23780 [11].

In contrast to the typical organization as a heterodimer, a fusion protein is encoded in the Sphe3 genome bearing the regions corresponding to the $\alpha$ and $\beta$ subunits of PCA 4,5dioxygenases and the predicted protein product PcaA demonstrated key conserved features of the enzyme as revealed by multiple sequence alignment (Figure S1). The structure of PcaA (Figure 7) was generated using homology modeling in Modeller [40]. Similarly to LigAB (pdbid: 1B4U) from S. paucimobilis SYK-6 [39], H35 $\beta, N 80 \beta, H 82 \beta$, and E264 $\beta$ correspond to 
the iron-binding residues, while residues S34 $\beta, \mathrm{H} 148 \beta, \mathrm{H} 217 \beta$, S296 $\beta$, and N297 $\beta$ interact specifically with the aromatic ring of PCA (the Greek character after the residue number corresponds to the subunit of PcaA that each residue is located). The coordination geometry of the non-heme Fe (II) in PcaA should follow the coordination geometry of the non-heme Fe (II) in DesB (pdbid: 3WRB) [41] and LigAB (pdbid: 1B4U) (Figures S6-S8). The four conserved histidine residues are found in four known motifs: SHXPA (H35 $\beta$ in PcaA) and NDHA (H80 $\beta$ in PcaA) in iron coordination, and DHG (H148 $\beta$ in PcaA) and GXSH (H217 $\beta$ in PcaA), which are characteristic of the novel PCAD-Memo superfamily $[14,15,42,43]$. An absolutely conserved aspartate residue is also present (D232 $\beta$ in PcaA) providing a stabilizing backbone contact that is crucial for delimiting the one side of the active site [14]. Contiguous DNA segments joined to form a single gene encoding for the large and small subunit of PCA 4,5-dioxygenases have been reported for Arthrobacter keyseri [30], Verminephrobacter eiseniae EF01-2, and Burkholderia phymatum STM815 [44].
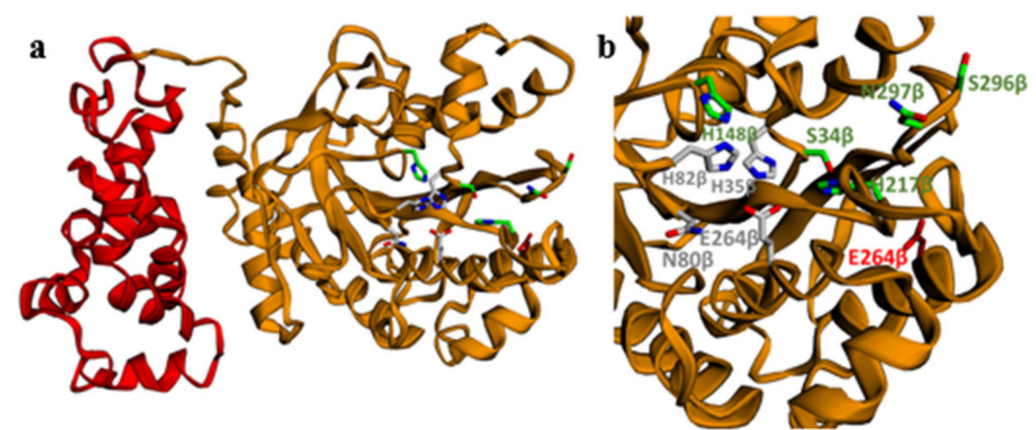

Figure 7. (a) The 3D structure of PcaA using homology modeling. Subunits $\alpha$ and $\beta$ are colored in red and orange, respectively. Conserved residues $\mathrm{H} 35 \beta, \mathrm{N} 80 \beta, \mathrm{H} 82 \beta$, and $\mathrm{E} 264 \beta$ are colored in gray and correspond to the iron-binding residues. The conserved residues S34 $\beta, H 148 \beta, H 217 \beta$, S296 $\beta$, and $\mathrm{N} 297 \beta$ that can interact specifically with the aromatic ring of PCA are colored in green. The highly conserved aspartate residue D322 $\beta$ is colored in red. (b) A closer view of subunit $\beta$ with details on the conserved residues.

Transcriptional analysis showed that the pcaA gene encoding the 4,5-PCA dioxygenase was induced during growth on PCA and phenanthrene. The higher pcaA mRNA transcript level upon PCA growth in comparison with the phenanthrene-grown cells could be attributed to a different regulatory mechanism, triggered by the presence of different carbon sources or even to the higher growth rate of Sphe3 in PCA compared to phenanthrene that could affect the $p c a$ A transcription $[45,46]$. Similar results were obtained by proteomic analysis of Sphe3 cells grown on phenanthrene or on phthalate, an intermediate metabolite of phenanthrene metabolism pathway [29].

The divergently directed LysR-type transcriptional regulator (LTTR) ( $p c a$ R), located upstream of the pca gene cluster in Sphe3, was induced in the presence of aromatics, with a 6 -fold higher induction for PCA. The minimal expression of $p c a \mathrm{R}$ gene during growth in the presence of glucose indicates a minimal basal constitutive expression, but in response to PCA or a metabolite thereof that act as inducers, PcaR can act as the transcriptional activator of the PCA meta-cleavage pathway in Sphe3, as has been reported for LTTRs in aromatic degradation pathways [47-49]. PcaR shows no similarity to any characterized LTTR but shares a $97 \%$ amino acid sequence identity with $p c m R$ found upstream the $p m c$ gene cluster in A. keyseri and whose role in regulation has not been studied [30]. Studies on the regulatory mechanisms of the PCA 4,5-cleavage pathway are scarce $[5,8,38]$ and given the fact that specific regulators among each bacterial group of Actinobacteria, $\alpha-, \beta-$ and $\gamma$-Proteobacteria diversely control transcription of PCA gene clusters [8], the study of the regulation of the PCA meta-cleavage pathway in Sphe3 in concert with the LysR-type protein and the possible influence of other regulatory elements remains to be clarified in the future. 
To the best of our knowledge, this is the first report on biochemical and kinetic characterization of a PCA 4,5-dioxygenase in the genus Arthrobacter. PCA 4,5-dioxygenase from P. phenanthrenivorans Sphe3 (PcaA) was overexpressed, purified, and characterized for its biochemical and kinetic properties.

The highest activity for the recombinant PCA 4,5-dioxygenase was recorded after $30 \mathrm{~min}$ of incubation in the presence of a $0.2 \mathrm{mM} \mathrm{FeSO}_{4} / \mathrm{L}$-ascorbic acid solution at $0{ }^{\circ} \mathrm{C}$. Like other type II extradiol dioxygenases, PCA 4,5-dioxygenase seems to depend on the presence of $\mathrm{Fe}(\mathrm{II})$ as a co-factor that is involved in the catalysis [13]. The apparent $K_{m}$ value of PcaA for PCA is lower than or similar to values reported for 4,5-dioxygenases from other organisms, even under different experimental conditions in some cases $(80 \mu \mathrm{M}$, Pseudomonas sp. [32]; $55.5 \mu \mathrm{M}$, C. testosteroni T-2 [15]; $46 \mu \mathrm{M}$, C. testosteroni NCIMB 8893 [50]; $20 \mu \mathrm{M}$, R. leguminosarum [11]; $51 \pm 4 \mu \mathrm{M}$, S. paucimobilis SYK-6 [12]; $5.26 \mu \mathrm{M}, R$. ruber P25 [31]), revealing a high affinity with PCA as a substrate. In contrast to the majority of extradiol ring-cleavage dioxygenases containing iron $\mathrm{Fe}(\mathrm{II})$ whose activity is decreased by the addition of chelators [12,13,51], the activity of PcaA is not significantly reduced in the presence of metal chelating agents (EDTA, bipy, o-phenanthroline). This indicates either that $\mathrm{Fe}(\mathrm{II})$ is tightly bound to the iron center of PcaA or that the latter is not easily accessible [12].

Non-heme iron extradiol dioxygenases have been reported to be catalytically active most commonly with $\mathrm{Fe}(\mathrm{II})$ but also with a variety of metal ions of the same oxidation state (e.g., $\mathrm{Mn}(\mathrm{II}), \mathrm{Co}(\mathrm{II}), \mathrm{Cu}(\mathrm{II}), \mathrm{Zn}(\mathrm{II})$ or $\mathrm{Ni}(\mathrm{II}))$ [51-53]. Of the divalent metal ions tested in the present study, only $\mathrm{Cu}(\mathrm{II})$ and $\mathrm{Mn}$ (II) were inhibitory and the same inhibitory effects of $\mathrm{Cu}$ (II) and $\mathrm{Mn}$ (II) have been also reported for other PCA 4,5-dioxygenases [12,50], allowing the assumption that they may out-compete Fe(II) for the occupation of the metal ion binding site. The optimum $\mathrm{pH}$ for PcaA catalysis is 9.5, which is consistent for PCA 4,5-dioxygenase of Pseudomonas sp. K82 and R. leguminosarum [11,54], whereas most of the bacterial PCA 4,5-dioxygenases have been reported to show the highest activity in a $\mathrm{pH}$ range of $7-8[12,17,32]$.

The narrow range of substrates catabolized by 4,5-PCA dioxygenase in Sphe3 denotes that the enzyme is highly specific to PCA. The lack of enzyme activity in the presence of homoprotocatechuate indicates that the carboxylate group is essential for the aromatic ring cleavage and cannot be replaced by a carboxymethyl group [55]. Additionally, the vicinal 3,4-diol has been considered crucial for the enzyme activity as benzoate, 4-hydroxybezoate, and 3-hydroxybenzoate showed no activity results that corroborate those reported for PmdAB from C. testosteroni T-2 [15] and LigAB from S. paucimobilis SYK-6 [12].

NMR analysis clearly illustrated the presence of two PCA biotransformation products due to keto-enol tautomerization, which has been previously reported to exist spectrophotometrically [56,57], whereas NMR resonances corresponding to the biotransformed product have not formerly been observed in the ${ }^{1} \mathrm{H}$ NMR spectrum [12]. An unequivocal confirmation of the tautomerization process was further confirmed with STD NMR. The formation of the keto tautomer was enthalpically favored, presumably due to hydrogen bonding to the carbonyl group; however, it was strongly entropically disfavored, thus resulting in a shift of the equilibrium towards the formation of the dominant enol form. It is well known that the keto-enol equilibrium in solution is very sensitive and related to polar/polarizability and hydrogen-bonding capability of solvents [58]. The enol tautomer was entropically favored and stabilized due to weaker intermolecular hydrogen bonding formation with the aqueous solvent and, thus, the least immobilization of the solvation molecules of $\mathrm{H}_{2} \mathrm{O}$. Since a buffer solution was used, it can be concluded that there is no change in the ionization state of the keto and enol tautomers due to temperature variation. Additionally, the OMA product resulting from the biotransformation of gallate has previously been characterized only by ${ }^{1} \mathrm{H}$ NMR spectroscopy; however, the reaction was not monitored inside the NMR tube [59].

${ }^{1} \mathrm{H}[60,61],{ }^{13} \mathrm{C}[62],{ }^{19} \mathrm{~F}$ [63], and ${ }^{31} \mathrm{P}[64,65]$ NMR has emerged as a powerful and reliable tool for the investigation of products of enzymatic reactions and for gaining insight into the kinetics of the reactions. More specifically, in situ NMR diffusion experiments were explored for their ability to profile reaction products with significantly different molecular 
weight over the course of enzymatic depolymerization of biological macromolecules [66]. ${ }^{19} \mathrm{~F}$ and ${ }^{31} \mathrm{P}$ NMR require the presence of the appropriate isotope in the ligands. ${ }^{13} \mathrm{C}$ NMR requires selectively enrichment in ${ }^{13} \mathrm{C}$ ligands and/or the use of hyperpolarization methods which require specialized NMR instrumentation [67]. The advantage of the present in situ monitoring approach of an enzymatic reaction by free enzyme in the NMR tube is that the complete characterization can be achieved by the combined use of $1 \mathrm{D}, 2 \mathrm{D},{ }^{1} \mathrm{H}$ ${ }^{1} \mathrm{H}$, and ${ }^{1} \mathrm{H}_{-}{ }^{13} \mathrm{C}$ HSQC and HMBC NMR spectroscopy. Furthermore, various restriction factors, including enzyme loss of activity and stability, substrate concentration limitations, temperature, and buffer limitations, made this study more challenging. However, we successfully performed the reaction in optimum conditions, monitored the reaction over time, and elucidated the structural components of the products. A basic advantage of the present method is that the enzyme is free in the solution and, therefore, it can adopt its natural conformation, which is an essential factor for a natural enzymatic biotransformation as a dynamic process. Furthermore, this approach minimizes the need for laborious sample preparation methods and purification steps, ultimately leading to more accurate real-time kinetic determination of enzymatic reactions.

\section{Materials and Methods}

\subsection{Bacterial Strains and Growth Conditions}

P. phenanthrenivorans Sphe $3^{\mathrm{T}}$ (formerly Arthrobacter phenanthrenivorans Sphe3 = DSM $18606^{\mathrm{T}}=$ LMG $23796^{\mathrm{T}}$ ) was isolated from a creosote-polluted area in Epirus, Greece [23]. Sphe3 was grown in M9 minimal medium (MM M9), as described previously [68], in the presence of phenanthrene $(15 \mathrm{mM})$, PCA $(5 \mathrm{mM})$ or glucose $(22 \mathrm{mM})$ as the sole carbon and energy sources, on a rotary shaker agitated at $180 \mathrm{rpm}$, at $30^{\circ} \mathrm{C}$. Escherichia coli DH5a and BL21(DE3) were cultured in lysogeny broth (LB) medium in the presence of Kanamycin $(\mathrm{Km})$ when necessary, for selection.

\subsection{Preparation of Sphe3 Cell Extracts}

Crude cell-free extracts were prepared as described previously [68] with a slight modification in the washing buffer $(10 \mathrm{mM}$ Tris- $\mathrm{HCl}, \mathrm{pH} 8.0$ containing $10 \mathrm{mM}$ DTT). Protein concentrations were determined spectrophotometrically by the method of Bradford, using the Bio-Rad reagent (Bio-Rad Laboratories, Hercules, CA, USA) and bovine serum albumin (BSA) (Amresco Inc., Solon, OH, USA) as a standard [69].

\subsection{Enzyme Assays}

The activity of PCA 4,5-dioxygenase under standard conditions was estimated spectrophotometrically as described by Ono et al. [32] with a slight modification in the reaction buffer (100 mM Glycine- $\mathrm{NaOH}, \mathrm{pH}$ 9.5). The reaction was initiated with the addition of the crude cell-free extract $(8 \mathrm{mg} / \mathrm{ml})$ or the recombinant purified PcaA solution $(0.15 \mathrm{mg} / \mathrm{ml})$. One enzyme unit is defined as the amount of enzyme that produces $1 \mu \mathrm{mol}$ of 2-hydroxy4-carboxymuconate-6-semialdehyde per minute at $20^{\circ} \mathrm{C}$. The kinetic parameters $K_{m}$ and $V_{\max }$ values were determined in a broad concentration range of PCA substrate varying from 0.015 to $15 \mathrm{mM}$, with Origin Microcal software, Version 6.0, ORIGIN [70], by nonlinear fitting of the Michaelis-Menten equation. All kinetic values are the means of three separate measurements. The effect of $\mathrm{pH}$ in the activity of recombinant PcaA was investigated in the $\mathrm{pH}$ range of 4 to 12 at room temperature. The buffer solutions $(100 \mathrm{mM})$ used to span this range were succinate- $\mathrm{NaOH}(\mathrm{pH} 4.0$ to 6.0), citrate- $\mathrm{NaOH}$ ( $\mathrm{pH}$ 6.5), phosphate ( $\mathrm{pH} 7.0$ ), Tris ( $\mathrm{pH} 7.5$ to 9), and glycine ( $\mathrm{pH} 9.5$ to 12). The optimal temperature for the PCA 4,5-dioxygenase was determined by conducting the above assays in a temperature range of 5 to $50^{\circ} \mathrm{C}$ in the optimal $\mathrm{pH}$.

The influence of different chelating agents on the PcaA activity was tested by incubating samples of the purified enzyme $(1 \mu \mathrm{M})$ with concentrations of EDTA, 2,2'-dipyridyl (2,2'-bipyridine) (bipy), or o-phenanthroline up to $10 \mu \mathrm{M}$ at $0{ }^{\circ} \mathrm{C}$ for $30 \mathrm{~min}$ in $100 \mathrm{mM}$ glycine-NaOH buffer $\mathrm{pH}$ 9.5. The enzyme reaction was initiated by adding $0.3 \mathrm{mM}$ PCA. 
The influence of different divalent metals on PcaA activity was estimated spectrophotometrically as above. The enzyme was incubated with concentrations of divalent metal salt solutions of $\mathrm{FeSO}_{4} \cdot 7 \mathrm{H}_{2} \mathrm{O} / \mathrm{L}$-ascorbic acid, $\mathrm{CuSO}_{4} \cdot 5 \mathrm{H}_{2} \mathrm{O}, \mathrm{MgSO}_{4} \cdot 7 \mathrm{H}_{2} \mathrm{O}, \mathrm{MnSO}_{4} \cdot \mathrm{H}_{2} \mathrm{O}$, and $\mathrm{NiCl}_{2} \cdot 6 \mathrm{H}_{2} \mathrm{O}$, ranging from $0.1-1 \mathrm{mM}$ and for time periods of $0,15,20$, and $30 \mathrm{~min}$ at $0{ }^{\circ} \mathrm{C}$.

All enzyme assays were performed at $20^{\circ} \mathrm{C}$ using a Shimadzu UV-1201 spectrophotometer (Triad Scientific, Inc., Manasquan, NJ, USA).

\subsection{Substrate Specificity Assessment}

A variety of potential substrates were screened by measuring $\mathrm{O}_{2}$ consumption using an $\mathrm{O}_{2}$-sensitive Clark type electrode with computer integration via an Oxygraph electrode control unit (HI 9143 Microprocessor Auto Cal Dissolved Oxygen Meter, HANNA instruments, Smithfield, RI, USA). The reaction mixture contained $0.3 \mathrm{mM}$ of the tested substrate solution, $0.15 \mathrm{mg} / \mathrm{ml}$ of purified enzyme, and $100 \mathrm{mM}$ glycine- $\mathrm{NaOH}$ buffer $\mathrm{pH} 9.5$ to a final volume of $2 \mathrm{~mL}$. Recombinant PcaA was added in order to initiate the reaction as previously described. Stock solutions of the organic substrates were prepared as $30 \mathrm{mM}$ solutions in $\mathrm{H}_{2} \mathrm{O}$ (PCA, gallate, 4-hydroxybezoate, 3-hydroxybenzoate, gentisate, phthalate, catechol, 3,4-dihydroxyphenylacetate), 1:9 DMSO/ $\mathrm{H}_{2} \mathrm{O}$ (benzoate, vanillin), or as $10 \mathrm{mM}$ solutions in 1:4 DMSO/ $\mathrm{H}_{2} \mathrm{O}$ (caffeic acid, $p$-coumaric acid).

\subsection{Cloning and Heterologous Expression of pcaA Gene}

The orf identified from in silico analysis of the Sphe3 genome that encodes the putative $\alpha$ and $\beta$ subunits of PCA 4,5-dioxygenase was found on an indigenous plasmid (pASPHE302) and annotated as pcaA. Sphe3 genomic DNA was isolated from phenanthrene grown cells using cetyltrimethylammonium bromide (CTAB) [71]. Primers Pca45diox for $_{\text {f }} /$ Pca45diox $_{\text {rev }}$ (Table S1) carrying NdeI-XhoI restriction sites and gDNA as template were used in a PCR reaction with conditions as described previously [68]. The $1302 \mathrm{bp}$ amplification product was cloned in pCR-blunt vector (Invitrogen, Thermo Fischer Scientific, Watham, MA, USA) for nucleotide sequence verification and subsequently subcloned

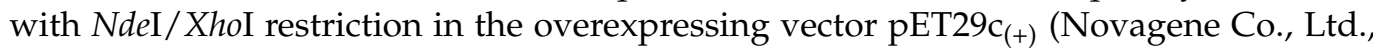
Beijing, China).

Amplification reactions were carried out in a PTC-100 version 7.0 thermocycler (MJ Research Inc., Waltham, MA, USA) using the Phusion High-Fidelity DNA polymerase (Finnzymes, Espoo, Finland) and $1.5 \mathrm{mM} \mathrm{MgCl}_{2}$ (final concentration). NucleoSpin Extract 2 in 1 (Macherey-Nagel GmbH \& Co. KG, Dueren, Germany) was used to purify the produced amplicons.

For E. coli strain DH5a as a recipient, host transformation was carried out according to Hanahan [72] and for BL21 (DE3) according to Chung and Miller [73]. Cloned fragments were sequenced by VBC Genomics Bioscience Research GmbH (Wien, Germany). Sequence alignments were performed using the program BLAST [74] at the NCBI website. Restriction enzyme digestions, ligation, and agarose gel electrophoresis were carried out using standard methodology [75]. Amino acid sequences exhibiting similarity were retrieved from protein databases and aligned using CLUSTALW (accessed on 5/4/2021) [76]. Phylogenetic tree and molecular evolutionary analyses were conducted using MEGA version 4 with the neighbor joining method [77].

\subsection{Purification of Recombinant PCA 4,5-Dioxygenase}

An E. coli BL21(DE3)-pET29c $\mathrm{c}_{(+)}$host-vector overexpression system was used to overproduce the PcaA polypeptide as described elsewhere [68].

The supernatant was applied to a $20 \mathrm{~mL}$ HisPrep FF 16/10 column (GE Healthcare, Chicago, IL, USA) using and AKTA FPLC system (GE Healthcare, Chicago, IL, USA). Column bound protein was washed with wash buffer $(100 \mathrm{mM}$ Tris- $\mathrm{HCl}, 500 \mathrm{mM} \mathrm{NaCl}$, $\mathrm{pH} 8.0$ containing $25 \mathrm{mM}$ imidazole) and then eluted with elution buffer (100 $\mathrm{mM}$ Tris- $\mathrm{HCl}$, $500 \mathrm{mM} \mathrm{NaCl}$, pH 8.0 containing $350 \mathrm{mM}$ imidazole). The elution buffer was exchanged 
with NMR buffer (50 mM Tris- $\mathrm{HCl}, 50 \mathrm{mM} \mathrm{NaCl}, 250 \mu \mathrm{M}$ DTT pH 8 ) and 10\% DMSO- $d_{6}$ was added for better enzyme stability.

\subsection{In situ Biotransfomation Monitoring in the NMR Tube}

First, $1 \mathrm{mM}$ of PCA was added to $8 \mu \mathrm{M}$ of enzyme in $0.6 \mathrm{~mL}$ of NMR buffer $90 \%$ $\mathrm{H}_{2} \mathrm{O}$ (50 mM Tris- $\mathrm{HCl}, 50 \mathrm{mM} \mathrm{NaCl}, 0.25 \mathrm{mM}$ DTT, pH 8) with $10 \%$ DMSO- $d_{6}$, then the sample was transferred to a $5 \mathrm{~mm}$ NMR tube. Similarly, $0.5 \mathrm{mM}$ of gallate was added to $8 \mu \mathrm{M}$ of enzyme in NMR buffer $90 \% \mathrm{H}_{2} \mathrm{O} 10 \%$ DMSO- $_{6}$ and transferred to a $5 \mathrm{~mm}$ NMR tube. NMR experiments were performed directly in the NMR tube and the enzymatic reaction was monitored over time. NMR experiments were performed on a Bruker AV500 spectrometer (Bruker Biospin, Rheinstetten, Germany) at $298 \mathrm{~K}$ using the Topsin 3.2 suite. Water suppression was achieved by the use of an excitation sculpting pulse sequence (zgesgp). The assignment and the description of the physicochemical properties of the reaction products was achieved using $1 \mathrm{D}^{1} \mathrm{H}$ and $2 \mathrm{D}$ NMR spectroscopy, ${ }^{1} \mathrm{H}-{ }^{1} \mathrm{H}$ COSY, ${ }^{1} \mathrm{H}_{-}{ }^{1} \mathrm{H}$ TOCSY, ${ }^{1} \mathrm{H}_{-}{ }^{13} \mathrm{C}$ HSQC, and ${ }^{1} \mathrm{H}_{-}{ }^{13} \mathrm{C}$ HMBC experiments. The 2D TOCSY NMR experiment was acquired using a mixing time of $60 \mathrm{~ms}$. Saturation transfer difference (STD) NMR experiment was performed with the selective saturation of a given ${ }^{1} \mathrm{H}$ frequency by a train of 40 Gaussian pulses with the duration of $50 \mathrm{~ms}$ each separated by a delay of $1 \mathrm{~ms}$, with total saturation time of $2 \mathrm{~s}$. The on-resonance irradiation was performed at a chemical shift of $9.17 \mathrm{ppm}$. Off-resonance irradiation was applied at $40 \mathrm{ppm}$, outside the spectra region of the ${ }^{1} \mathrm{H}$ NMR resonances. STD spectrum was obtained by the subtraction of the on-resonance from the off-resonance spectrum.

\subsection{Transcriptional Analysis with RT-PCR and Quantitative Real-Time PCR (RT-qPCR)}

Total RNA isolation was performed as described elsewhere [32]. For RT-PCR analysis the Robust ${ }^{\mathrm{TM}}$ II RT-PCR Kit (Finnzymes Oy, Thermo Fischer Scientific, Espoo, Finland) was used according to the manufacturer's instructions and primers (Table S1) designed to amplify the six gene junctions (Figure S1A). RT-qPCR was performed as described previously [68] with a modification in cDNA synthesis, where the PrimeScript ${ }^{\mathrm{TM}}$ RT reagent kit with gDNA eraser (Perfect Real Time, Takara Bio Inc., Kusatsu, Shiga, Japan) was used according to the manufacturer's instructions.

The efficiency (E) of one cycle RT-qPCR in the exponential phase was found to be 1.89-2.2 $\left(\mathrm{E}=10^{(-1 / \text { slope })}[78,79]\right.$ with correlation factors $\left.0.9894<R^{2}<0.9918\right)$. The housekeeping gene was used as the reference gene and gene expression levels in glucose were used as calibrator gyr $\beta$. The results were analyzed by the relative quantification method [80].

\subsection{D Model Construction of PcaA}

The 3D model of PcaA was generated by homology modeling, using standard routines in the MODELLER 10.0 software [40]. Three known structures with pdbids, 1B4U, 3WRB, and $3 \mathrm{MQU}$, were used as templates. The pairwise alignment of the PcaA sequence with the sequences of known structures used for the modeling can be found in Supplementary Material (embedded alignment.pdf accessed on 8 August 2021). The generated model was visualized with EzMol [81]. The figures of the non-heme Fe (II) site of $3 \mathrm{WRB}$ and 1B4U were generated with Mol*Viewer 2.2.1 (https://molstar.org/viewer/, accessed on 8 August 2021) [82].

Supplementary Materials: The following are available online at https:/ /www.mdpi.com/article/10 $.3390 /$ ijms22179647/s1.

Author Contributions: A.-I.K. conceived and supervised the study; E.T. designed and performed the overexpression and characterization of PcaA; E.V. designed and performed RT-PCR; A.P. and E.T. designed and performed AKTA FPLC purification of PcaA; A.P., E.T., A.G.T. and I.P.G. designed and performed NMR experiments; S.A. designed and performed RT-qPCR; A.G.T. constructed the 3D PcaA structure; E.T., E.V., A.P. and S.A. analyzed data; A.-I.K., E.T., E.V., A.P. and S.A. wrote the manuscript; A.-I.K. made manuscript revisions. All authors have read and agreed to the published version of the manuscript. 
Funding: Part of this research is co-financed by Greece and the European Union European Social Fund-ESF) through the operational program "Human Resources Development, Education and Lifelong Learning" in the context of the project "Strengthening Human Resources Research Potential via Doctorate Research" (MIS-5000432, approved 13 November 2018), implemented by the State Scholarships Foundation (IKY). IKY had no involvement in study design; in the collection, analysis and interpretation of data; in the writing of the report; or in the decision to submit the article for publication.

Institutional Review Board Statement: Not applicable.

Informed Consent Statement: Not applicable.

Data Availability Statement: All data generated or analyzed during this study are included in this published article (and its Supplementary Information File).

Acknowledgments: We thank E. Papamichael, University of Ioannina, for his contribution to the determination of kinetic constants.

Conflicts of Interest: The authors declare no conflict of interest.

\section{References}

1. Kamimura, N.; Masai, E. The protocatechuate 4, 5-cleavage pathway: Overview and new findings. In Biodegradative Bacteria; Nojiri, H., Tsuda, M., Fukuda, M., Kamagata, Y., Eds.; Springer: Tokyo, Japan, 2014; pp. 207-226. [CrossRef]

2. Crawford, R.L. Novel pathway for degradation of protocatechuic acid in Bacillus species. J. Bacteriol. 1975, 121, 531-536. [CrossRef]

3. Kasai, D.; Fujinami, T.; Abe, T.; Mase, K.; Katayama, Y.; Fukuda, M.; Masai, E. Uncovering the protocatechuate 2, 3-cleavage pathway genes. J. Bacteriol. 2009, 191, 6758-6768. [CrossRef]

4. Harwood, C.S.; Parales, R.E. The $\beta$-ketoadipate pathway and the biology of self-identity. Ann. Rev. Microbiol. 1996, 50, 553-590. [CrossRef]

5. Kamimura, N.; Aoyama, T.; Yoshida, R.; Takahashi, K.; Kasai, D.; Abe, T.; Mase, K.; Katayama, Y.; Fukuda, M.; Masai, E. Characterization of the protocatechuate 4,5-cleavage pathway operon in Comamonas sp. strain E6 and discovery of a novel pathway gene. Appl. Environ. Microbiol. 2010, 76, 8093-8101. [CrossRef] [PubMed]

6. Bugg, T.D.; Ahmad, M.; Hardiman, E.M.; Rahmanpour, R. Pathways for degradation of lignin in bacteria and fungi. Nat. Prod. Rep. 2011, 28, 1883-1896. [CrossRef]

7. Sim, H.W.; Jung, M.; Cho, Y.K. Purification and characterization of protocatechuate 3, 4-dioxygenase from Pseudomonas pseudoalcaligenes KF707. J. Korean Soc. Appl. Biol. Chem. 2013, 56, 401-408. [CrossRef]

8. Ni, B.; Zhang, Y.; Chen, D.W.; Wang, B.J.; Liu, S.J. Assimilation of aromatic compounds by Comamonas testosteroni: Characterization and spreadability of protocatechuate 4, 5-cleavage pathway in bacteria. Appl. Microbiol. Biotechnol. 2013, 97, 6031-6041. [CrossRef] [PubMed]

9. Bugg, T.D.; Ahmad, M.; Hardiman, E.M.; Singh, R. The emerging role for bacteria in lignin degradationand bioproduct formation. Curr. Opin. Biotechnol. 2011, 22, 394-400. [CrossRef] [PubMed]

10. Pérez-Pantoja, D.; Donoso, R.; Junca, H.; González, B.; Pieper, D.H. Phylogenomics of aerobic bacterial degradation of aromatics. In Aerobic Utilization of Hydrocarbons, Oils and Lipids; Rojo, F., Ed.; Springer: Cham, Switzerland, 2017; pp. 1-48. [CrossRef]

11. Chen, Y.P.; Lovell, C.R. Purification and properties of a homodimeric protocatechuate 4, 5-dioxygenase from Rhizobium leguminosarum. Arch. Microbiol. 1994, 161, 191-195. [CrossRef]

12. Barry, K.P.; Taylor, E.A. Characterizing the promiscuity of LigAB, a lignin catabolite degrading extradiol dioxygenase from Sphingomonas paucimobilis SYK-6. Biochemistry 2013, 52, 6724-6736. [CrossRef] [PubMed]

13. Vaillancourt, F.H.; Bolin, J.T.; Eltis, L.D. The ins and outs of ring-cleaving dioxygenases. Crit. Rev. Biochem. Mol. Biol. 2006, 41, 241-267. [CrossRef] [PubMed]

14. Burroughs, A.M.; Glasner, M.E.; Barry, K.P.; Taylor, E.A.; Aravind, L. Oxidative opening of the aromatic ring: Tracing the natural history of a large superfamily of dioxygenase domains and their relatives. J. Biol. Chem. 2019, 294, 10211-10235. [CrossRef] [PubMed]

15. Mampel, J.; Providenti, M.A.; Cook, A.M. Protocatechuate 4, 5-dioxygenase from Comamonas testosteroni T-2: Biochemical and molecular properties of a new subgroup within class III of extradiol dioxygenases. Arch. Microbiol. 2005, 183, 130-139. [CrossRef] [PubMed]

16. Providenti, M.A.; Mampel, J.; MacSween, S.; Cook, A.M.; Wyndham, R.C. Comamonas testosteroni BR6020 possesses a single genetic locus for extradiol cleavage of protocatechuate. Microbiology 2001, 147, 2157-2167. [CrossRef]

17. Maruyama, K.; Shibayama, T.; Ichikawa, A.; Sakou, Y.; Yamada, S.; Sugisaki, H. Cloning and characterization of the genes encoding enzymes for the protocatechuate meta-degradation pathway of Pseudomonas ochraceae NGJ1. Biosc. Biotechnol. Biochem. 2004, 68, 1434-1441. [CrossRef] [PubMed] 
18. Masai, E.; Shinohara, S.; Hara, H.; Nishikawa, S.; Katayama, Y.; Fukuda, M. Genetic and biochemical characterization of a 2-pyrone-4, 6-dicarboxylic acid hydrolase involved in the protocatechuate 4, 5-cleavage pathway of Sphingomonas paucimobilis SYK-6. J. Bacteriol. 1999, 181, 55-62. [CrossRef] [PubMed]

19. Wattiau, P.; Bastiaens, L.; van Herwijnen, R.; Daal, L.; Parsons, J.R.; Renard, M.E.; Springael, D.; Cornelis, G.R. Fluorene degradation by Sphingomonas sp. LB126 proceeds through protocatechuic acid: A genetic analysis. Res. Microbiol. 2001, 152, 861-872. [CrossRef]

20. Noda, Y.; Nishikawa, S.; Shiozuka, K.; Kadokura, H.; Nakajima, H.; Yoda, K.; Katayama, Y.; Morohoshi, N.; Haraguchi, T.; Yamasaki, M. Molecular cloning of the protocatechuate 4, 5-dioxygenase genes of Pseudomonas paucimobilis. J. Bacteriol. 1990, 172, 2704-2709. [CrossRef]

21. Patil, N.K.; Kundapur, R.; Shouche, Y.S.; Karegoudar, T. Degradation of a plasticizer, di-n-butylphthalate by Delftia sp. TBKNP-05. Curr. Microbiol. 2006, 52, 225-230. [CrossRef]

22. Busse, H.J. Review of the taxonomy of the genus Arthrobacter, emendation of the genus Arthrobacter sensu lato, proposal to reclassify selected species of the genus Arthrobacter in the novel genera Glutamicibacter gen. nov., Paeniglutamicibacter gen. nov., Pseudoglutamicibacter gen. nov., Paenarthrobacter gen. nov. and Pseudarthrobacter gen. nov., and emended description of Arthrobacter roseus. Int. J. Syst. Evol. Microbiol. 2016, 66, 9-37. [CrossRef]

23. Kallimanis, A.; Kavakiotis, K.; Perisynakis, A.; Spröer, C.; Pukall, R.; Drainas, C.; Koukkou, A. Arthrobacter phenanthrenivorans sp. nov., to accommodate the phenanthrene-degrading bacterium Arthrobacter sp. strain Sphe3. Inter. J. Syst. Evol. Microbiol. 2009, 59, 275-279. [CrossRef]

24. Kallimanis, A.; Frillingos, S.; Drainas, C.; Koukkou, A.I. Taxonomic identification, phenanthrene uptake activity, and membrane lipid alterations of the PAH degrading Arthrobacter sp. strain Sphe3. App. Microbiol. Biotechnol. 2007, 76, 709-717. [CrossRef] [PubMed]

25. Kallimanis, A.; LaButti, K.M.; Lapidus, A.; Clum, A.; Lykidis, A.; Mavromatis, K.; Pagani, I.; Liolios, K.; Ivanova, N.; Goodwin, L. Complete genome sequence of Arthrobacter phenanthrenivorans type strain (Sphe3). Stand. Genomic. Sci. 2011, 4, 123. [CrossRef] [PubMed]

26. Chatterjee, S.; Dutta, T.K. Complete degradation of butyl benzyl phthalate by a defined bacterial consortium: Role of individual isolates in the assimilation pathway. Chemosphere 2008, 70, 933-941. [CrossRef]

27. Niewerth, H.; Schuldes, J.; Parschat, K.; Kiefer, P.; Vorholt, J.A.; Daniel, R.; Fetzner, S. Complete genome sequence and metabolic potential of the quinaldine-degrading bacterium Arthrobacter sp. Rue61a. BMC Genom. 2012, 13, 534. [CrossRef]

28. Pau, M.Y.; Davis, M.I.; Orville, A.M.; Lipscomb, J.D.; Solomon, E.I. Spectroscopic and electronic structure study of the enzyme-substrate complex of intradiol dioxygenases: Substrate activation by a high-spin ferric non-heme iron site. J. Am. Chem. Soc. 2007, 129, 1944-1958. [CrossRef]

29. Vandera, E.; Samiotaki, M.; Parapouli, M.; Panayotou, G.; Koukkou, A.I. Comparative proteomic analysis of Arthrobacter phenanthrenivorans Sphe3 on phenanthrene, phthalate and glucose. J. Proteom. 2015, 113, 73-89. [CrossRef] [PubMed]

30. Eaton, R.W. Plasmid-encoded phthalate catabolic pathway in Arthrobacter keyseri 12B. J. Bacteriol. 2001, 183, 3689-3703. [CrossRef]

31. Plotnikova, E.; Solyanikova, I.; Egorova, D.; Shumkova, E.; Golovleva, L. Degradation of 4-chlorobiphenyl and 4-chlorobenzoic acid by the strain Rhodococcus ruber P25. Microbiology 2012, 81, 143-153. [CrossRef]

32. Ono, K.; Nozaki, M.; Hayaishi, O. Purification and some properties of protocatechuate 4, 5-dioxygenase. Biochim. Biophys. Acta 1970, 220, 224-238. [CrossRef]

33. Chatzikonstantinou, A.V.; Tsiailanis, A.D.; Gerothanassis, I.P.; Stamatis, H.; Ravera, E.; Fragai, M.; Luchinat, C.; Parigi, G.; Tzakos, A.G. The NMR tube bioreactor. Methods Enzymol. 2020, 633, 71-101. [CrossRef]

34. Chatzikonstantinou, A.V.; Chatziathanasiadou, M.V.; Ravera, E.; Fragai, M.; Parigi, G.; Gerothanassis, I.P.; Luchinat, C.; Stamatis, H.; Tzakos, A.G. Enriching the biological space of natural products and charting drug metabolites, through real time biotransformation monitoring: The NMR tube bioreactor. Biochim. Biophys. Acta Gen. Subj. 2018, 1862, 1-8. [CrossRef]

35. Primikyri, A.; Sayyad, N.; Quilici, G.; Vrettos, E.I.; Lim, K.; Chi, S.W.; Musco, G.; Gerothanassis, I.P.; Tzakos, A.G. Probing the interaction of a quercetin bioconjugate with Bcl-2 in living human cancer cells with in-cell NMR spectroscopy. FEBS Lett. 2018, 592, 3367-3379. [CrossRef]

36. Primikyri, A.; Mazzone, G.; Lekka, C.; Tzakos, A.G.; Russo, N.; Gerothanassis, I.P. Understanding zinc(II) chelation with quercetin and luteolin: A combined NMR and theoretical study. J. Phys. Chem. B 2015, 119, 83-95. [CrossRef]

37. Troganis, A.N.; Sicilia, E.; Barbarossou, K.; Gerothanassis, I.P.; Russo, N. Solvation properties of N-substituted cis and trans amides are not identical: Significant enthalpy and entropy changes are revealed by the use of variable temperature $1 \mathrm{H}$ NMR in aqueous and chloroform solutions and ab initio calculations. J. Phys. Chem. A 2005, 109, 11878-11884. [CrossRef]

38. Kamimura, N.; Takamura, K.; Hara, H.; Kasai, D.; Natsume, R.; Senda, T.; Katayama, Y.; Fukuda, M.; Masai, E. Regulatory system of the protocatechuate 4, 5-cleavage pathway genes essential for lignin downstream catabolism. J. Bacteriol. 2010, 192, 3394-3405. [CrossRef] [PubMed]

39. Sugimoto, K.; Senda, T.; Aoshima, H.; Masai, E.; Fukuda, M.; Mitsui, Y. Crystal structure of an aromatic ring opening dioxygenase LigAB, a protocatechuate 4, 5-dioxygenase, under aerobic conditions. Structure 1999, 7, 953-965. [CrossRef]

40. Webb, B.; Sali, A. Comparative protein structure modeling using MODELLER. Curr. Protoc. Bioinform. 2016, 54, 5-6. [CrossRef] [PubMed] 
41. Sugimoto, K.; Senda, M.; Kasai, D.; Fukuda, M.; Masai, E.; Senda, T. Molecular mechanism of strict substrate specificity of an extradiol dioxygenase, DesB, derived from Sphingobium sp. SYK-6. PLoS ONE 2014, 9, e92249. [CrossRef]

42. Eltis, L.D.; Bolin, J.T. Evolutionary relationships among extradiol dioxygenases. J. Bacteriol. 1996, 178, 5930-5937. [CrossRef]

43. Peng, X.; Egashira, T.; Hanashiro, K.; Masai, E.; Nishikawa, S.; Katayama, Y.; Kimbara, K.; Fukuda, M. Cloning of a Sphingomonas paucimobilis SYK-6 gene encoding a novel oxygenase that cleaves lignin-related biphenyl and characterization of the enzyme. Appl. Environ. Microbiol. 1998, 64, 2520-2527. [CrossRef]

44. Pérez-Pantoja, D.; Donoso, R.; Agulló, L.; Córdova, M.; Seeger, M.; Pieper, D.H.; González, B. Genomic analysis of the potential for aromatic compounds biodegradation in Burkholderiales. Environ. Microbiol. 2012, 14, 1091-1117. [CrossRef] [PubMed]

45. Duetz, W.A.; Marqués, S.; Wind, B.; Ramos, J.L.; van Andel, J. Catabolite repression of the toluene degradation pathway in Pseudomonas putida harboring pWW0 under various conditions of nutrient limitation in chemostat culture. Appl. Environ. Microbiol. 1996, 62, 601-606. [CrossRef] [PubMed]

46. Blencke, H.M.; Homuth, G.; Ludwig, H.; Mäder, U.; Hecker, M.; Stülke, J. Transcriptional profiling of gene expression in response to glucose in Bacillus subtilis: Regulation of the central metabolic pathways. Metab. Eng. 2003, 5, 133-149. [CrossRef]

47. Tropel, D.; van der Meer, J.R. Bacterial transcriptional regulators for degradation pathways of aromatic compounds. Microbiol. Mol. Biol. Rev. 2004, 68, 474-500. [CrossRef]

48. Jiménez, J.I.; Miñambres, B.; García, J.L.; Díaz, E. Genomic analysis of the aromatic catabolic pathways from Pseudomonas putida KT2440. Environ. Microbiol. 2002, 4, 824-841. [CrossRef]

49. Romero-Silva, M.J.; Mendez, V.; Agullo, L.; Seeger, M. Genomic and functional analyses of the gentisate and protocatechuate ring-cleavage pathways and related 3-hydroxybenzoate and 4-hydroxybenzoate peripheral pathways in Burkholderia xenovorans LB400. PLOS ONE 2013, 8, e56038. [CrossRef]

50. Dagley, S.; Geary, P.; Wood, J. The metabolism of protocatechuate by Pseudomonas testosteroni. Biochem. J. 1968, 109, 559. [CrossRef]

51. Nogales, J.; Canales, Á.; Jiménez-Barbero, J.; García, J.L.; Díaz, E. Molecular characterization of the gallate dioxygenase from Pseudomonas putida KT2440 the prototype of a new subgroup of extradiol dioxygenases. J. Biol. Chem. 2005, 280, 35382-35390. [CrossRef]

52. Whiting, A.K.; Boldt, Y.R.; Hendrich, M.P.; Wackett, L.P.; Que, L. Manganese (II)-dependent extradiol-cleaving catechol dioxygenase from Arthrobacter globiformis CM-2. Biochemistry 1996, 35, 160-170. [CrossRef]

53. Fielding, A.J.; Kovaleva, E.G.; Farquhar, E.R.; Lipscomb, J.D.; Que, L. A hyperactive cobalt-substituted extradiol-cleaving catechol dioxygenase. J. Biol. Inor. Chem. 2011, 16, 341-355. [CrossRef]

54. Yun, S.H.; Yun, C.Y.; Kim, S.I. Characterization of protocatechuate 4, 5-dioxygenase induced from p-hydroxybenzoate-cultured Pseudomonas sp. K82. J. Microbiol. 2004, 42, 152-155.

55. Zabinski, R.; Münck, E.; Champion, P.; Wood, J. Kinetic and Mössbauer studies on the mechanism of protocatechuic acid 4, 5-oxygenase. Biochemistry 1972, 11, 3212-3219. [CrossRef] [PubMed]

56. Ribbons, D.; Evans, W. Oxidative metabolism of protocatechuic acid by certain soil pseudomonads: A new ring-fission mechanism. Biochem. J. 1962, 83, 482. [CrossRef] [PubMed]

57. Masai, E.; Momose, K.; Hara, H.; Nishikawa, S.; Katayama, Y.; Fukuda, M. Genetic and Biochemical characterization of 4-Carboxy2-Hydroxymuconate-6-Semialdehyde dehydrogenase and its role in the protocatechuate 4, 5-cleavage pathway in Sphingomonas paucimobilis SYK-6. J. Bacteriol. 2000, 182, 6651-6658. [CrossRef] [PubMed]

58. Chakraborty, I.; Bodurtha, K.J.; Heeder, N.J.; Godfrin, M.P.; Tripathi, A.; Hurt, R.H.; Shukla, A.; Bose, A. Massive electrical conductivity enhancement of multilayer graphene/polystyrene composites using a nonconductive filler. ACS Appl. Mater. Interfaces 2014, 6, 16472-16475. [CrossRef]

59. Nogales, J.; Canales, Á.; Jiménez-Barbero, J.; Serra, B.; Pingarrón, J.M.; García, J.L.; Díaz, E. Unravelling the gallic acid degradation pathway in bacteria: The gal cluster from Pseudomonas putida. Mol. Microbiol. 2011, 79, 359-374. [CrossRef]

60. Brecker, L.; Ribbons, D.W. Biotransformations monitored in situ by proton nuclear magnetic resonance spectroscopy. Trends Biotechnol. 2000, 18, 197-202. [CrossRef]

61. Yang, T.; Bar-Peled, M. Identification of a novel UDP-sugar pyrophosphorylase with a broad substrate specificity in Trypanosoma cruzi. Biochem. J. 2010, 429, 533-543. [CrossRef]

62. Kopp, D.; Willows, R.D.; Sunna, A. Cell-free enzymatic conversion of spent coffee grounds into the platform chemical lactic acid. Front. Bioeng Biotechnol. 2019, 7, 389. [CrossRef]

63. Dalvit, C. Ligand-and substrate-based ${ }^{19}$ F NMR screening: Principles and applications to drug discovery. Progr. NMR Spectrosc. 2007, 51, 243-271. [CrossRef]

64. Werner, R.M.; Johnson, A. ${ }^{31}$ P NMR of the pyruvate kinase reaction: An undergraduate experiment in enzyme kinetics. Biochem. Mol. Biol. Educ. 2017, 45, 509-514. [CrossRef] [PubMed]

65. Escobedo-Hinojosa, W.; Wissner, J.L.; Hauer, B. A real-time ${ }^{31} \mathrm{P}-\mathrm{NMR}$-based approach for the assessment of glycerol kinase catalyzed monophosphorylations. Methods X 2021, 8, 101285. [CrossRef]

66. Limtiaco, J.F.; Beni, S.; Jones, C.J.; Langeslay, D.J.; Larive, C.K. NMR methods to monitor the enzymatic depolymerization of heparin. Anal. Bioanal. Chem. 2011, 399, 593-603. [CrossRef] [PubMed]

67. Korchak, S.; Jagtap, A.P.; Glöggler, S. Signal-enhanced real-time magnetic resonance of enzymatic reactions at millitesla fields. Chem. Sci. 2021, 12, 314-319. [CrossRef] 
68. Vandera, E.; Kavakiotis, K.; Kallimanis, A.; Kyrpides, N.C.; Drainas, C.; Koukkou, A.I. Heterologous expression and characterization of two 1-hydroxy-2-naphthoic acid dioxygenases from Arthrobacter phenanthrenivorans. Appl. Environ. Microbiol. 2012, 78, 621-627. [CrossRef]

69. Bradford, M.M. A rapid and sensitive method for the quantitation of microgram quantities of protein utilizing the principle of protein-dye binding. Anal. Biochem. 1976, 72, 248-254. [CrossRef]

70. Deschenes, L.A.; David, A. Origin 6.0: Scientific Data Analysis and Graphing Software Origin Lab Corporation (Formerly Microcal Software, Inv.); BoutUniversity of Texas, Austin; Commercial price: 595; Academic price: 446; 2000. pp. 9567-9568. Available online: www.originlab.com (accessed on 18 March 2017).

71. William, S.; Feil, H.; Copeland, A. Bacterial Genomic DNA Isolation using CTAB. DOE Joint Genome Institute, Walnut Creek, CA 2012. Available online: https://jgi.doe.gov/wp-content/uploads/2014/02/JGI-Bcterial-DNA-isolation-CTAB-Protocol-2012.pdf (accessed on 18 March 2017).

72. Hanahan, D. Studies on transformation of Escherichia coli with plasmids. J. Mol. Biol. 1983, 166, 557-580. [CrossRef]

73. Chung, C.; Miller, R.H. A rapid and convenient method for the preparation and storage of competent bacterial cells. Nucleic Acids Res. 1988, 16, 3580. [CrossRef]

74. Altschul, S.F.; Madden, T.L.; Schäffer, A.A.; Zhang, J.; Zhang, Z.; Miller, W.; Lipman, D.J. Gapped BLAST and PSI-BLAST: A new generation of protein database search programs. Nucleic Acids Res. 1997, 25, 3389-3402. [CrossRef]

75. Sambrook, J.; Fritsch, E.; Maniatis, T. Molecular Cloning: A Laboratory Manual, 2nd ed.; Cold Spring Harbor Laboratory Press: New York, NY, USA, 1989.

76. Thompson, J.D.; Higgins, D.G.; Gibson, T.J. CLUSTAL W: Improving the sensitivity of progressive multiple sequence alignment through sequence weighting, position-specific gap penalties and weight matrix choice. Nucleic Acids Res. 1994, 22, 4673-4680. [CrossRef] [PubMed]

77. Tamura, K.; Dudley, J.; Nei, M.; Kumar, S. MEGA4: Molecular evolutionary genetics analysis (MEGA) software version 4.0. Mol. Biol. Evol. 2007, 24, 1596-1599. [CrossRef] [PubMed]

78. Pfaffl, M.W. A new mathematical model for relative quantification in real-time RT-PCR. Nucleic Acids Res. 2001, 29, e45. [CrossRef]

79. Corbella, M.; Puyet, A. Real-time reverse transcription-PCR analysis of expression of halobenzoate and salicylate catabolismassociated operons in two strains of Pseudomonas aeruginosa. Appl. Environ. Microbiol. 2003, 69, 2269-2275. [CrossRef]

80. Applied Biosystems. Relative Quantifcation of Gene Expression in User Bulletin 2 ABI PRISM 7700 Sequence Detection System; Applied Biosystems: Waltham, MA, USA, 1999; pp. 1-36.

81. Reynolds, C.R.; Islam, S.A.; Sternberg, M.J. EzMol: A web server wizard for the rapid visualization and image production of protein and nucleic acid structures. J. Mol. Biol. 2018, 430, 2244-2248. [CrossRef] [PubMed]

82. Sehnal, D.; Bittrich, S.; Deshpande, M.; Svobodová, R.; Berka, K.; Bazgier, V.; Velankar, S.; Burley, S.K.; Koča, J.; Rose, A.S. Mol* Viewer: Modern web app for 3D visualization and analysis of large biomolecular structures. Nucleic Acids Res. 2021. [CrossRef] 